\title{
Ownership Influences On Vertical B2B E-marketplaces' Survival
}

\author{
Weijun Zheng \\ School of Business and Technology, \\ University of Wisconsin-Parkside, Kenosha, WI, USA
}

\section{zheng@uwp.edu}

\begin{abstract}
A vertical electronic marketplace (EM) is an inter-organizational intermediary within a single industry that enables participating buyers and sellers to exchange information about price and product offerings and to cooperate on commodity exchange. Using a Relational View (RV) perspective, this paper develops theoretical arguments that explain the impact of ownership on the like lihood of vEM survival. With a survival analys is, this paper provides empirical support for the theoretical arguments using data collected on 159 vEMs across six industries. The paper found that EM ownerships with industry ties will have higher survival rates than those without.
\end{abstract}

Key words : B2B electronic marketplace, ownership model, relational view

\section{Introduction}

An vertical electronic marketplaces (EM) is a virtual hub, enabled by information, decision, and communication technologies, embedded in a single industry network, the objective of which is to bring together multiple buyers and suppliers to exchange information, complete transactions and otherwise interact (Zwass, 1999). B2B e-marketplaces has proliferated through the late 1990s. According to Gartner Research, more than 3,000 electronic marketplaces were launched year 2003. In just about every industry - from automobile manufacturing to chemical production EMs have been created to handle the buying and selling of goods and services between manufacturers and suppliers. However, this explos ion of EMs created overcrowded landscapes within many industries. Intensive competition has resulted in roughly $45 \%$ of EMs failed to survive up (Day, Fein, \& Ruppersberger, 2003), either ceasing operations or being acquired by another EM (White, Daniel, Ward, \& Wilson, 2007). While EMs continue to prove their business values to the industries, as evidenced by 2.37 trillion historic high transaction volume generated through EMs on 2004 (eMarketer, 2003), it is increasingly important to investigate the survivor characteristics of EMs in order to understand the underlying competition drivers.

Ownership (i.e., the identities of a firm's equity holders and the sizes of their positions) concerns

Material published as part of this publication, either on-line or in print, is copyrighted by the Informing Science Institute. Permission to make digital or paper copy of part or all of these works for personal or classroom use is granted without fee provided that the copies are not made or distributed for profit or commercial advantage AND that copies 1) bear this notice in full and 2) give the full citation on the first page. It is permissible to abstract these works so long as cred it is given. To copy in all other cases or to republish or to post on a server or to redistribute to lists requires specific permission and payment of a fee. Contact Publisher@InformingScience.org to request redistribution permission. the right to possess and use property to the exclusion of others (Williamson, 1985). EM ownership, often classified by the owners' characteristics such as owner(s)' prior membership within an existing industry network, is a reflective of the controlling stakeholders of EMs who have the right to possess and use EM property to the exclusion of others. Prior literature has found that 
ownership influences managerial incentives (Jensen \& Meckling, 1976), firm performance (Demsetz \& Villalonga, 2001; Kle in, 1998), legitimacy (Evan \& Freeman, 1993; Luoma \& Goodstein, 1999), and organizational learning (Helper \& Levine, 1992; Mohr \& Sengupta, 2002). EM ownership lies at the heart of EM governance because the rights to control or make strategic decisions are provided in board rights and in voting rights, both of which are directly re lated to ownership (Kaplan \& Stromberg 2003). Ownership is thus expected to significantly influence EM competition and EMs' survival (Woods, 2002). Surprisingly, as of today, few studies have empirically tested the influences of ownerships on EM's survival.

The goal of this paper is set to investigate the survival status of vertical EMs by their ownerships. The paper, for the first time, provided empirical evidences on the survival prospects of EMs by their ownership characteristics and rationalized industry network impact on EMs' survival by ownership. The paper first identified three major EM ownerships and then reviewed relevant literatures. Hypothesis is then proposed, followed by methodologies and testing results. The conclusion is given at the end.

\section{EM Ownership}

EM ownership represents a significant source of organizational variation. Over the years, three primary EM ownerships have emerged: independent ownership, the consortium ownership and the private ownership ( Kambil \& Van Heck, 2002).

An independent EM is an EM established by third parties distinct from the EM's targeted buyers and sellers. Independent EMs such as Chemdex and Partminer, are owned by industry outs iders and typically commence market development without the buy-in commitment of key market participants. While the EM owners often hire a management team with industry experience and existing relationships with some of these market participants, these relationships tend to be fragile. A consortia EM is established by a group of key market partic ipants, typically buyers or sellers but not both. These consortia offer major industry players the opportunity to obtain the benefits of embedding an EM within the industry network but retaining a substantial portion of the value generated through the EM amongst them rather than allowing it to flow to a third party. The founders of these marketplaces typically represent a substantial portion of the industry's trading volume, and thus possess the potential to marginalize competing EMs. For example, the twentyone founding members of Quadrem, the EM for mining, minerals, and metals companies, represent two-thirds of the industry's total market capitalization and more than $25 \%$ of its buying power. Private EMs, on the other hand, are trading platforms set up by individual companies to directly reach their key suppliers or customers. Examples include Cisco and Dell and Walmart's private exchange. Private EMs are usually set up by companies with a dominant industry position or leading supply chain management capabilities.

\section{Literature Review}

In order to survive in the overcrowded industry landscape, an EM must develop its competitive advantages that allow the EM to earn above-average returns, compared to other EMs in the same industry. The Resource-Based View(RBV) points out that a firm's sustained competitive advantage is derived from the "resources and capabilities a firm controls that are valuable, rare, imperfectly imitable, and not substitutable" (M. Barney, Wright, \& Ketchen, 2001). Those resources can be things such as assets, organizational characteristics, processes, aptitudes, information and know ledge controlled by the company and its employees (J. Barney, 1991). Lately, the Relational View (RV) literature complements RBV by focusing on the relational resources created by the interaction between specific partners who then generate a relational rent (Dyer \& Singh, 1998). The RV literature suggests that a firm's critical resources may span the firm's boundaries and may be embedded in inter-firm resources and routines (Dyer \& Singh, 1998; Peteraf, 1994). 
Firms invest in relation-specific assets, knowledge-sharing routines, and complementary resources and capabilities in conjunction with other affiliated firms' assets or investment within the inter-firm relationships. Those investments are relational resources that can create competitive barriers, reduce inter-firm transaction costs and induce inter-firm innovations(Dyer, 1996, 1997; Dyer \& Chu, 2003; Dyer \& Nobeoka, 2003).

The ownership model of a firm is a reflective of its controlling stakeholders and conveys the relational resources associated with those stakeholders. Ownership is directly related to the board rights and voting rights that provide the rights to control or make strategic decisions (Kaplan \& Stromberg, 2003). Control of resources, especially relational resources, is hardly separated from ownership within a network of firms. The controllers of those relational resources frequently have some degree of ownership of the equity of the firms they participate; while some owners, by virtue of the size of their equity positions, effectively have some control of the relationships the firm has.

\section{Hypothesis}

An vertical EM(vEM) is essentially an inter-organizational information system that allows the participating buyers and sellers to cooperate on information and commodity exchanges. Ownerships have been recognized as particularly salient to vEM success(Chatterjee \& Segars, 2003). Ownership by industry participants and ownership without those participants make a great difference in an EM's control of relationship resources and is expected to influence the survival of an EM.

From the RV theoretic perspective, the representation of industry participants on EMs' boards brings into an EM those industry insiders' network relationships and enables the EM to leverage participant owners' relationship resources in operation. This is because: first, the possession or control of relationship resources by EM participant owners may make other value chain partners dependent on the EM for transactions and legitimize the EM's operation. If those participant owners possess enough bargaining power in their value chain, EMs can be formed to tighten the bonds between participant owners and their value chain partners (Chatterjee \& Segars, 2003). Second, the relationships of participant owners are often attributed by trust, commitment, mutual goals, and social bonding etc. Those attributes can form hard to replicate management mechanis ms and routines that provide protection against opportunistic behavior in transactions, and thus make the use of participant owned EMs more appealing in the industry. Finally, the relationships that participant owners are embedded also provide the EMs the ability to (Dyer \& Singh, 1998; Powell, Koput, \& Smith-Doerr, 1996). Such a resourceful network position was shown to contribute to rapid firm growth and likely to lead to more future collaboration opportunities among network participants (Powell et al., 1996). In general, participant owned EMs are able to leverage critical resources that independent owned EMs don't have, which will help them to develop the ir competitive advantages against those non-participant owned EMs.

Both consortia EMs and private EMs involve industry participants in their ownership and therefore enjoy valuable industry ties from their participant owners, while independent EMs typically lack (Driedonks, Gregor, Wassenaar, \& Van Heck, 2005; Fong, Fow ler, \& Swatman, 1998). Although some independent EMs can be created and managed by professional from the industry, their ties to the industry are non-institutional and much weaker, which generally not able to create significant relational rents. In comparison, the industry ties that both consortia EMs and private EMs enjoy are more influential in the coordination of market activities and the development of cooperation within the industry network (Driedonks et al., 2005; Dyer \& Singh, 1998; Kambil \& Short, 1994). Ultimately they are expected to give consortia EMs and private EMs competitive advantages in their survival in comparison to those independent EMs, and thus higher survival rate. 
Hypothesis 1: EM ownerships with industry ties will have higher survival rates than those without.

\section{Methodology}

To investigate the survival prospects of various EM ownerships, a data set describing $158 \mathrm{EMs}$ from 6 industries including apparel, pharmaceutical, automobile, aerospace, metal, and semiconductor was assembled by content analysis based on data from various comprehensive lists of vertical B2B EMs (over the 1997-2004 time frame) including: eMarketServices.com, Forbes.com, Jupiter Media Matrix, and B2B business.net. Search engines were used to locate other EM lists and other EMs in these six industries but no additional EMs were identified. Once the sample pool was identified, an EM profile was compiled based on evidence collected from the EM's current website, older versions of the EM's website as maintained by the web archive and the LexisNexis newswire database. Two reviewers systematically examined each EM's profile, categorizing the EMs based on their ownerships. The reliability of reviewers was calculated with Cohen's Kappa--a generally robust measure of concordance for dichotomous data (Fleiss, 1981) and is as high as $70 \%$. After data collection, a Kaplan-Meier survival analysis was applied to analyze the relationships between EM ownerships and EM survival longevity.

The K-M method, also known as product-limit estimator, estimates the cumulative survival function at the time each event occurs (Allison, 1984, 1995). It is useful for preliminary examination of the data since its produces K-M curves that represent the proportion of the study population still surviving (or free of disease or some other outcome) at successive times. The K-M curves for the intervention of interest and the comparator are often represented on the same graph and a pvalue can be calculated to determine the likelihood that there is no-difference between the two survival curves.

The dependent variable in this research is EM longevity - a duration variable, whose hazard function obtained through survival analysis would allow us to incorporate time to gauge the increasing or decreasing effects of a predictor such as EM ownerships the intervening period (P. Allison, 1984). The EM survival longevity was calculated by the duration years between the starting year of the EM and the ending year of the EM or the censoring time (year 2006), whichever comes first. Whether an EM is censored or not was indicated by the survival status of each EM by the year 2006. The independent variable in this study is EM ownership by the founding year of the EMs. Such a survival analys is will explic itly show the effects of EM ownerships on EM survival time.

\section{Results}

Table 1 gives the sample distribution in this paper. Figure 1 presents the histogram of EM survival time in the sample of this research. The frequency analysis indicates that the median time for EM longevity in the samples of this research is 6 years, and the highest failure rate occurs during the first year from an EM's launch.

Table 1. EM Sample Distributions by Owne rship

\begin{tabular}{|c|c|c|c|}
\hline Owne rship & Total & \multicolumn{2}{|c|}{ EM Survival? (by 2006) } \\
\hline & & Yes & No \\
\hline Independent & 104 & 54 & 50 \\
\hline Consortia & 21 & 16 & 5 \\
\hline Private & 33 & 23 & 10 \\
\hline Total & $\mathbf{1 5 8}$ & $\mathbf{9 3}$ & $\mathbf{6 5}$ \\
\hline
\end{tabular}




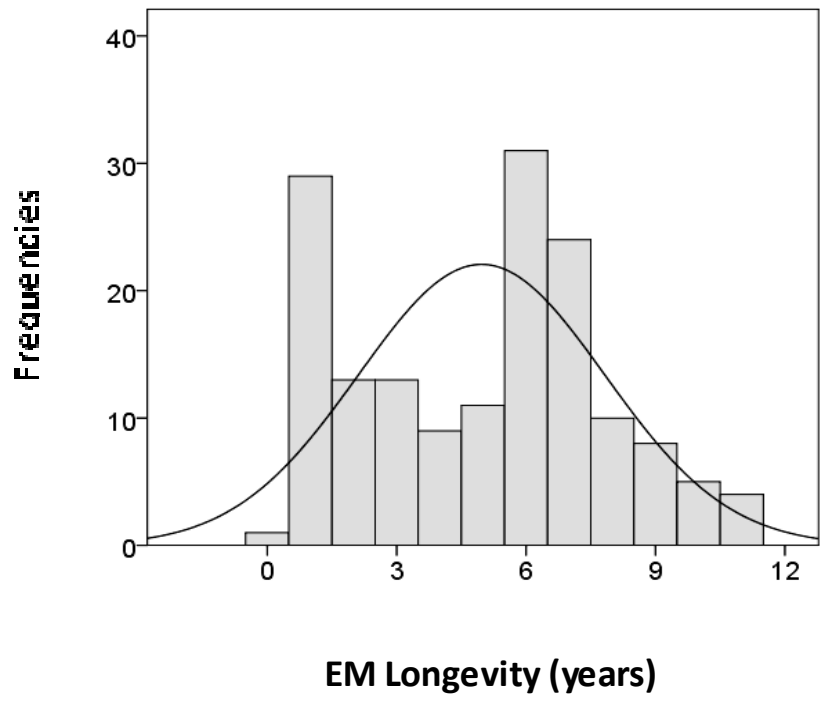

Figure 1. His togram of EM Survival Longevity

In conducting the Kaplan-Meier survival analys is, the researcher first compared the three EM ownership groups with the nonparametric Kaplan-Meier estimate. The test results in Table 2 suggest that the differences among independent ownerships, consortia ownerships, and private ownerships are approaching significance with both log-rank and Tarone-Ware statistics lower than 0.09 and Wilcoxon statistics equal to 0.1 . Since both consortia and private ownerships enjoy the relationship resources brought in by the ir industry participant owners, those two ownerships were then combined into one group as opposed to independent ownership that has no ties with the industry network. Table 2 also includes this following up test results, in which all three KM estimates are significant at 95\% confidence level, indicating that EMs with independent ownerships have signif icant lower survival chances than those have industry participant owners.

Table 2 Kaplan-Meier Test of EM Survival Longevity by Owne rships

\begin{tabular}{|c|c|c|c|c|c|c|}
\hline $\begin{array}{c}\text { Comparison } \\
\text { Groups }\end{array}$ & \multicolumn{2}{|c|}{$\begin{array}{c}\text { Three Ownership Groups } \\
\text { (inde pendent, consortia, } \\
\text { and private) }\end{array}$} & \multicolumn{3}{|c|}{$\begin{array}{c}\text { Two Ownership Groups } \\
\text { (independent vs. } \\
\text { non-independent) }\end{array}$} \\
\hline Test & Chi-S quare & DF & $\begin{array}{c}\text { Pr > } \\
\text { Chi- } \\
\text { Square }\end{array}$ & $\begin{array}{c}\text { Chi- } \\
\text { Square }\end{array}$ & DF & Pr > Chi-Square \\
\hline Log-Rank & 5.516 & 2 & .063 & 5.373 & 1 & .020 \\
\hline Wilcoxon & 4.604 & 2 & .100 & 4.303 & 1 & .038 \\
\hline Tarone-Ware & 4.901 & 2 & .086 & 4.664 & 1 & .031 \\
\hline
\end{tabular}

A further examination of the survival curves for EM ownerships in the two tests gave more explanation to the test results. From Figure 2, the three survival curves for independent, consortia, and private ownerships start to diverse after the first year. The survival probability of private ownership EMs is lower than that of consortia but higher than that of independent ownership EMs. This is probably because consortia ownerships formed by a group of industry participant owners, created richer industry relationship resources than private ownership EMs. The influence of relationship resources on EM survival is even clearer in Figure 3, where independent ownership EMs have significantly lower survival probabilities than non-independent ownership EMs. Finally, the survival curves in Figure 2 and 3 also indicate that the differences among EM owner- 
ships are larger as time pass by. EMs face great challenges in the ir earlier years for many reasons. But in the long run, EM ownership has determinant effects on the survival of EMs. These findings support Hypothes is 1.

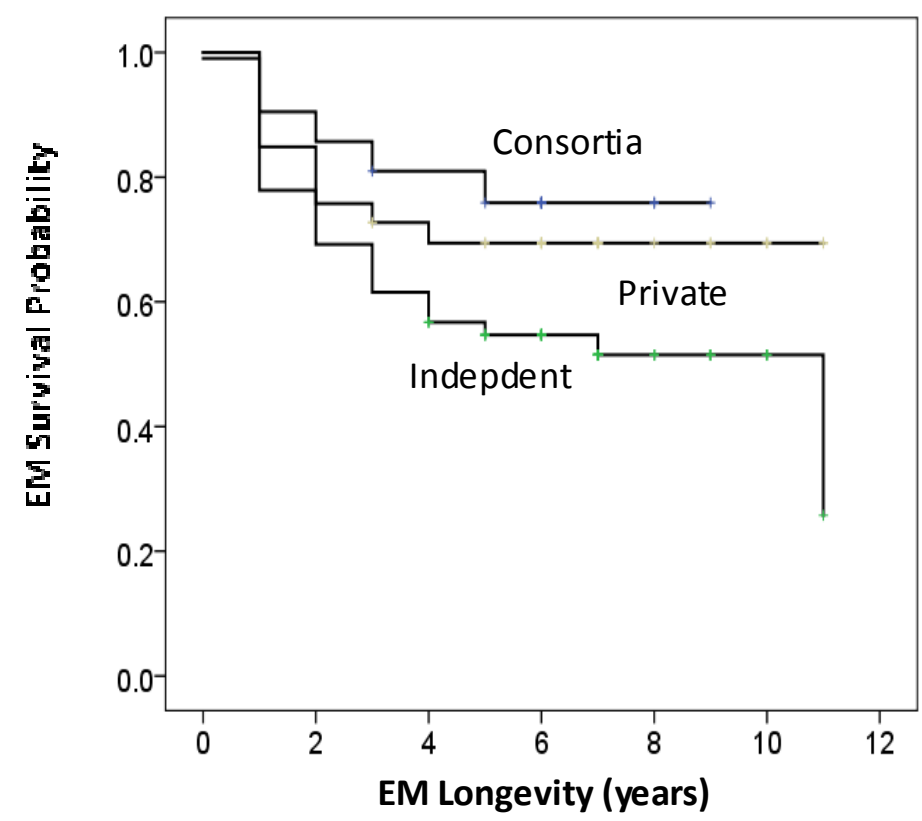

Figure 2. Estimation of EM Survival Function between Independent, Consortia, and Private Ownerships

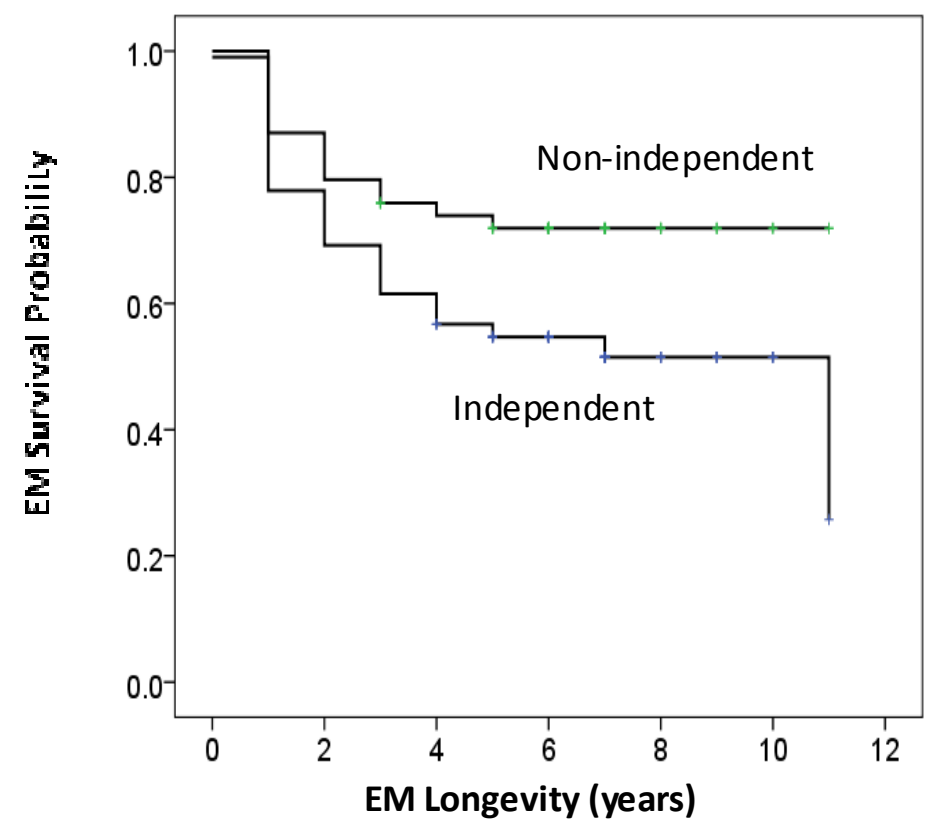

Figure 3. Estimation of EM Survival Function between Inde pende nt vs. Non-Inde pendent Ownerships 


\section{Conclusion}

The emergence of EMs in later 90s and the burst of Internet bubble in early 2000s were magnificent phenomenon in the adoption of new information intermediary technologies in the industries. Studies of EMs' survival and its underlying reasons contribute to our understanding of the EM phenomenon and build the foundation for future EM designs. This research found that ownerships that can induce industry partic ipants' cooperation and thus permit EMs to leverage relationship resources of those participants will have better survivability than those that cannot. The findings of this study clearly demonstrate the deterministic influences of ownership on the survival of EMs in the long run. This result is valuable to both EM creators and participants. For the former, they need to understand the survival chances of different EM ownerships and their competitive advantages in their entrepreneur activities. For perspective EM participants, either buyers or sellers, it is important to evaluate the values and costs of their strategies in joining an e-marketplace through different ownerships. The paper also contributes to existing EM literature in that it is the first empirical study linking ownership with EM survival. It highlights the importance of corporate governance structure and relationship resources in the success of IT innovation. Future EM researchers might want to explore further along this line of thinking.

It is worthwhile to point out that the paper has constraints in several aspects. First, there is a dearth of archival information regarding EM survival as most of EMs are privately-held rather than publicly-owned. This problem creates coding challenges on the failure years for those that have failed. Second, the K-M method applied here is a useful tool for preliminary examination and detection of ownership factor in EM survival. However, it misses the impacts of other control variables, e.g., industry environments, on EM survival. Future researches need to explore further on the other characteristics of EM and their associations with EM survival. Finally, this study focused on the first 10 years of existence of this new organizational form. While we expect our research model to hold as vEMs mature within the ir respective fields, assessing foundlings, organizational designs and survival propensities over an extended period of time would clearly be advantageous.

\section{References}

Allison, P. (1984). Event history analysis. Beverly Hills, CA. Sage Publications.

Allison, P. D. (1995). Survival analysis using SAS: A practical guide. Cary, NC, USA: SAS Publishing.

Barney, J. (1991). Firm resources and sustained competitive advantage. Journal of Management, 17(1), 99120.

Barney, M. Wright, \& Ketchen, D. J. (2001). The resource-based view of the firm: Ten years after 1991. Journal of Management, 27, 625.

Chatterjee, D., \& Segars, A. H. (2003). Transformation of the enterprise through e-business: An overview of contemporary practice and trends: Final report to the Advanced Practices Council.

Day, G. S., Fein, A. J., \& Ruppersberger, G. (2003). Shakeouts in digital markets: Lessons from B2B exchanges. California Management Review, 45(2), 131-150.

Demsetz, H., \& Villa longa, B. (2001). Ownership structure and corporate performance. Journal of Corporate Finance, 7, 209-233.

Driedonks, C., Gregor, S., Wassenaar, A., \& Van Heck, E. (2005). Econo mic and social analysis of the adoption of B2B electronic marketplaces: A case study in the Australian beef industry. International Journal of Electronic Commerce, 9(3) 49-72.

Dyer, J. H. (1996). Specialized supplier networks as a source of competitive advantage: Evidence from the Auto Industry. Strategic Management Journal, 17(4), 271-292. 
Dyer, J. H. (1997). Effective interfirm collaboration: How firms minimize transaction costs and maximize transaction value. Strategic Management Journal, 18, 553-556.

Dyer, J. H., \& Chu, W. (2003). The role of trustworthiness in reducing transaction costs and improving performance: Empirical evidence from the United States, Japan and Korea. Organisation Science, 14, 57-68.

Dyer, J. H., \& Nobeoka, K. (2003). Creating and managing a high-performance knowledge-sharing network: The Toyota case. Strategic Management Journal, 21(3), 345-367.

Dyer, J. H., \& Singh, H. (1998). The relational view: Cooperative strategy and sources of interorganizational competitive advantage. Academy of Management, 23(4), 660-680.

eMarketer Report on Europe E-Commerce: B2B and B2C. (2003) .eMarketer.

Evan, W. F., \& Freeman, R. E. (1993). A stakeholder theory of the modern corporation: Kantian capitalis m. Ethical Theory and Business, 75-84.

Fle iss, J. L. (1981). Statistical methods for rates and proportions. New York City, NY: John Wiley \& Sons.

Fong, T., Fowler, D., \& Swatman, P. M. C. (1998). Success and failure factors for implementing effective electronic markets. Electronic Markets, 8(1), 45 - 47.

Helper, S., \& Levine, D. I. (1992). Long-term supplier relations and product-market structure. Journal of Law, Economics \& Organization, 8(3), 561-581.

Jensen, M. C., \& Meckling, W. H. (1976). Theory of the firm: Managerial behavior, agency cost and ownership structure. Journal of Financial Economics, 3, 305 - 360.

Kambil, A., \& Short, J. E. (1994). Electronic integration and busines s network redesign: A roles-linkage perspective. Journal of Management Information Systems, 10(4), 59-84.

Kambil, A., \& Van Heck, E. (2002). Making markets: How firm can design and profit from online auctions and exchanges. Harvard Business School Press,.

Kaplan, S. N., \& Stro mberg, P. (2003). Financial contracting theory meets the real world: An emp irical analys is of venture capital contracts. Review of Economic Studies, 70, 281-315.

Kle in, A. (1998). Firm performance and board committee structure. Journal of Law and Economics, 41(1), 275-303.

Luo ma, P., \& Goodstein, J. (1999). Stakeholders and corporate boards: Institutional influences on board composition and structure. Academy of Management Journal, 42(5), 553-564.

Mohr, J. J., \& Sengupta, S. (2002). Managing the paradox of inter-firm learning: The role of governance mechanis ms. Journal of Business \& Industrial Marketing, 17(4), 282-301.

Peteraf, M. A. (1994). Commentary. Advances in strategic management, 1, 153-158.

Powell, W. W., Koput, K. W., \& Smith-Doerr, L. (1996). Interorganizational collaboration and the locus of innovation: Networks of learning in biotechnology Administrative Science Quarterly, 41(1), 116-145.

White, A., Daniel, E., Ward, J., \& W ilson, H. (2007). The adoption of consortium B2B E-marketplaces: An exploratory study. The Journal of Strategic Information Systems, 16(1).

Williamson, O. E. (1985). The Economic institutions of capitalism. New York: Free Press.

Woods, W. W. A. (2002). B2B exchanges 2.0: Not all e-markets are 'dot-bombs'. Bermuda: ISI Publications.

Zwass, V. (1999). Structure and macro-level impacts of electronic commerce: From technological tnfrastructures. In Kendall, K. (Ed.), Emerging information: Technology improving decisions, cooperation, and infrastructure (pp. 289-316). Thousand Oaks, CA: Sage Publications. 


\section{Biography}

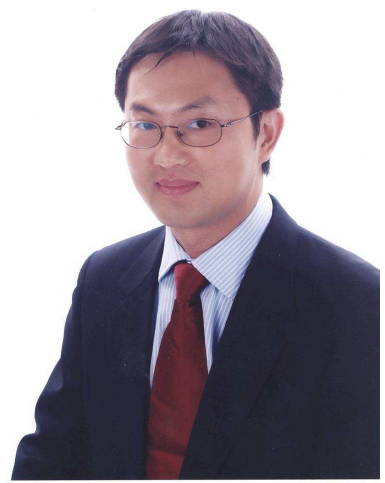

Dr. Weijun Zheng is an assistant professor in School of Business \& Technology, University of Wiscons in-Parkside. His research falls in the intersection of organization, technology, and management, with a focus on the strategy, design, and impacts of electronic market on industry value chain, IT innovation adoption and diffusion, IT offshore outsourc ing. His research methodology involves both quantitative analys is and qualitative study. His research has been published in multiple journals inc luding MIS Quarterly, Information Systems and eBusiness Management (ISeB), Communications of the International Information Management Association (IIMA), etc. 